\title{
Maternal serum anti-Müllerian hormone levels in pregnant women with gestational diabetes
}

\author{
Begüm Aydoğan Mathyk', Berna Aslan Çetin ${ }^{2}$ \\ ${ }^{1}$ Gynecology and Obstetrics Clinic, Şişli Etfal Hamidiye Training and Research Hospital, İstanbul, Turkey \\ ${ }^{2}$ Gynecology and Obstetrics Clinic, Kanuni Sultan Süleyman Training and Research Hospital, Istanbul, Turkey
}

\begin{abstract}
Objective: Serum anti-Müllerian hormone (AMH) levels are associated with conditions such as polycystic ovarian syndrome and obesity as well as being the marker of ovarian reserve. The aim of our study is to reveal if there is any difference between pregnant women diagnosed with gestational diabetes (GD) and healthy pregnant women in terms of third trimester AMH levels or not.

Methods: Pregnant women with GD who were newly diagnosed during between 24 and 28 weeks of gestation were included in the study. The demographic characteristics, weeks of gestation, delivery week and newborn weights of all patients included in the study were recorded. The demographic characteristics, clinical and laboratory parameters, gestational outcomes and serum AMH values of the patients were compared with the control group which had similar characteristics.

Results: Maternal body mass index (BMI), fasting blood glucose (FBG) and postprandial blood glucose (PBG) levels were significantly higher in the GD group than the control group. Mean serum AMH levels were similar in GD and control groups $(1.37 \pm 0.80 \mathrm{ng} / \mathrm{ml}$ and $1.52 \pm 0.99$ $\mathrm{ng} / \mathrm{ml})$. There was no significant correlation among serum AMH values, BMI, and FBG and PBG levels $(r=-0.04, p=0.72 ; r=-0.03, p=0.75$; $\mathrm{r}=-0.10, \mathrm{p}=0.40$, respectively). No significant impact was observed in the multiple linear regression analysis including the parameters such as age, BMI and week of gestation which may affect AMH level.

Conclusion: Third trimester serum AMH levels seem similar in pregnant women with and without the diagnosis of GD.
\end{abstract}

Keywords: Gestational diabetes, anti-Müllerian hormone.

\section{Introduction}

Anti-Müllerian hormone (AMH), also called as Müllerian inhibiting substance (MIS), is a glucoprotein which is a member of transforming growth factor beta

\section{Özet: Gestasyonel diyabetli gebelerde maternal serum anti-Müllerian hormon düzeyleri}

Amaç: Serum anti-Müllerian hormon (AMH) düzeyleri over rezervinin belirteci olmasının dışında polikistik over sendromu ve obezite gibi durumlarla da ilişkilidir. Çalışmamızın amacı gestasyonel diyabet (GD) tanısı olan gebelerle sağlıklı gebeler arasında üçüncü trimester AMH düzeyleri arasında fark olup olmadığını ortaya koymaktır.

Yöntem: Çalışmaya gebeliğinin 24. ve 28. haftaları arasında yeni tanı konulmuş GD'li gebeler dahil edildi. Çalışmaya alınan tüm hastaların demografik özellikleri, gebelik haftası, doğum haftası, yenidoğan ağırlıkları kaydedildi. Hastaların demografik özellikleri, klinik ve laboratuvar parametreleri, gebelik sonuçları ve serum AMH değerleri benzer özelliklere sahip kontrol grubu ile karşılaştrirldi.

Bulgular: Maternal vücut-kitle indeksi (VKI), açlık kan şekeri (AKŞ) ve tokluk kan şekeri (TKŞ) düzeyleri GD grubunda kontrol grubuna göre anlamlı olarak daha yüksekti. GD ve kontrol gruplarının ortalama serum AMH değerleri benzerdi $(1.37 \pm 0.80 \mathrm{ng} / \mathrm{ml}$ ve $1.52 \pm 0.99 \mathrm{ng} / \mathrm{ml})$. Serum AMH değerleri, VKİ, AKŞ ve TKŞ değerleri arasında anlamlı bağıntı yoktu (sırasıyla $\mathrm{r}=-0.04, \mathrm{p}=0.72$; $\mathrm{r}=-0.03, \mathrm{p}=0.75 ; \mathrm{r}=-0.10, \mathrm{p}=0.40)$. AMH düzeyine etki edebilecek yaş, VKİ ve gestasyonel hafta parametrelerini içeren çoklu doğrusal regresyon analizinde anlamlı etkileri gözlenmedi.

Sonuç: Üçüncü trimester serum AMH düzeyleri, GD tanısı alan ve almayan gebelerde benzer görünmektedir.

Anahtar sözcükler: Gestasyonel diyabet, anti-Müllerian hormon.

(TGF- $\beta$ ) family. ${ }^{[1]}$ AMH is synthesized from preantral and antral follicles in the ovarian granulosa cells. ${ }^{[2]}$ In clinical practice, $\mathrm{AMH}$ is an essential marker to assess the ovarian reserve, and its level does not change dur-
Correspondence: Berna Aslan Çetin, MD. Clinic of Obst. \& Gyn., Kanuni Sultan Süleyman Training and Research Hospital, Istanbul, Turkey. e-mail: bernaaslan14@hotmail.com Received: June 4, 2018 ; Accepted: July 23, 2018

Please cite this article as: Aydoğan Mathyk B, Aslan Çetin B. Maternal serum anti-Müllerian hormone levels in pregnant women with gestational diabetes. Perinatal Journal 2018;26(2):74-77.

(02018 Perinatal Medicine Foundation
Available online at: www.perinataljournal.com/20180262004 doi: $10.2399 /$ prn.18.0262004 QR (Quick Response) Code:

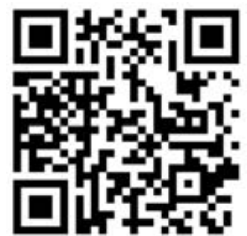


ing different periods of menstrual cycle. In the studies performed in recent years, it has been shown that serum AMH levels may be associated with metabolic conditions such as polycystic ovarian syndrome (PCOS) and obesity in addition to ovarian reserve. . $^{[3,4]}$

Although it has been reported in the literature that AMH levels decrease after 20 weeks of gestation, some studies did not consider this reduction significant. The reason is that $\mathrm{AMH}$ production is independent from gonadotropins. Menstrual cycle in pregnancy becomes inactive with the feedback effect and new follicle development is inhibited. The decrease of AMH levels in pregnancy is a result of the inhibition of follicles. AMH levels start to increase after a short time following the delivery. ${ }^{[5]}$ Diabetes is a common complication seen during pregnancy, and insulin resistance at second trimester and concomitant hyperinsulinemia create a diabetogenic condition during pregnancy. Gestational diabetes mellitus (GDM) is the glucose intolerance seen during pregnancy and its incidence is between $2 \%$ and $5 \% \cdot{ }^{[6,7]}$

In the literature, an association was shown between serum AMH levels and HOMA-IR levels which is the parameter of insulin resistance. ${ }^{[3]}$ Since insulin resistance also develops in gestational diabetes, the aim of our study is to reveal if there is any difference between pregnant women diagnosed with GDM and healthy pregnant women in terms of third trimester AMH levels or not.

\section{Methods}

Pregnant women with GDM who were newly diagnosed during between 24 and 28 weeks of gestation and healthy pregnant women with similar characteristics were included in this cross-sectional study. Our study was conducted between June 2014 and June 2015 at Şişli Etfal Training and Research Hospital after the approval of ethics committee was obtained. The consents of all patients included in the study were received.

Pregnant women with GDM diagnosis over 32 weeks and healthy pregnant women who were known as the control group or who did not have any diagnosed gestational disease were included in the study. Pregnant women whose data could not be accessed completely, twin pregnancies, pregnancies under 32 weeks, patients with pregestational diabetes and those with preeclampsia diagnosis were excluded from the study. Also, the cases with the surgical history of endometrioma/endometriosis and polycystic ovarian syndrome history were excluded from the study.

Two-step oral glucose tolerance test (OGTT) was performed between 24 and 28 weeks of gestation for all pregnant women included in the study. After 50-g glucose challenge test, plasma glucose levels were measured from the peripheral blood sample at the first hour of the procedure. For the patients whose 1-hour plasma glucose levels were $140 \mathrm{mg} / \mathrm{dl}$ and above, 3-hour 100-g OGTT was applied on a different day in order to establish GDM diagnosis according to CarpenterCoustan criteria. The plasma glucose value was 95 $\mathrm{mg} / \mathrm{dl}$ for fasting blood glucose, $180 \mathrm{mg} / \mathrm{dl}$ for $1 \mathrm{st}$ hour, $155 \mathrm{mg} / \mathrm{dl}$ for $2 \mathrm{nd}$ hour and $140 \mathrm{mg} / \mathrm{dl}$ for $3 \mathrm{rd}$ hour. The cases whose at least two of these values were found to be higher were considered GDM. ${ }^{[8]}$

The demographic characteristics, weeks of gestation, delivery week and newborn weights of all patients included in the study were recorded. The age, gravida, parity, body mass index (BMI), smoking habit, clinical and laboratory parameters, gestational outcomes and serum $\mathrm{AMH}$ values of the patients were compared. After the samples were collected in lithium-heparin tubes, serum AMH level was measured by Cobas device (Roche Diagnostics, Risch-Rotkreuz, Switzerland) using Elecsys reagent kit (Elecsys Corporation, Lenexa, KS, USA) by 'ECLIA' method which is electrochemiluminescence immunologic test.

The data of the cases included in the study were analyzed by Statistical Package for the Social Sciences (SPSS 20.0) (SPSS Inc, Chicago, IL, USA). The data were presented as mean \pm standard deviation. Independent $t$ test was used for the numerical parameters with identified normal distribution in order to analyze the statistical difference between the study groups. Chi-square test was used for the categorical data. Spearman's correlation analysis was carried out to find the correlation between the data. Multiple linear regression analysis was done for factors which may affect serum AMH levels. $\mathrm{p}<0.05$ was considered statistically significant.

\section{Results}

Of 72 patients included in the study, 35 patients were in the GDM group and 37 patients were in the control group. No difference was found in terms of maternal age, gravida, parity, smoking habit and the week of ges- 
tation when $\mathrm{AMH}$ was measured. Also, there was no difference between two groups in terms of week of gestation at delivery, and 1-minute and 5-minute Apgar scores (Table 1).

Maternal BMI, fasting blood glucose (FBG) and postprandial blood glucose (PBG) levels were significantly higher in the GDM group than the control group. Newborn weight was also found higher in the GDM group. A significantly positive correlation was found between newborn weight and maternal BMI $(\mathrm{r}=0.25, \mathrm{p}=0.03)$. No significant correlation was found between newborn weight and FBG and PBG ( $\mathrm{r}=0.03$, $\mathrm{p}=0.76$ for FBG; $\mathrm{r}=0.21, \mathrm{p}=0.06$ for $\mathrm{PBG}$ ).

In terms of $\mathrm{AMH}$ values, there was no statistically significant difference. Serum AMH values were found $1.37 \pm 0.80 \mathrm{ng} / \mathrm{ml}$ in the GDM group and $1.52 \pm 0.99$ $\mathrm{ng} / \mathrm{ml}$ in the control group. There was no statistically significant correlation between serum AMH values and BMI ( $\mathrm{r}=-0.04, \mathrm{p}=0.72)$. Also, there was no significant correlation between serum AMH values and FBG and PBG checked at second trimester $(r=-0.03, p=0.75$ for FBG; $\mathrm{r}=-0.1, \mathrm{p}=0.4$ for $\mathrm{PBG}$ ). No significant impact was observed in the multiple linear regression analysis including the parameters such as age, BMI and week of gestation which may affect AMH level. In the results of

Table 1. Comparison of demographic characteristics, laboratory data and delivery outcomes of GDM and control groups.

\begin{tabular}{lccc} 
& $\begin{array}{c}\text { GDM } \\
(\mathbf{n}=35)\end{array}$ & $\begin{array}{c}\text { Control } \\
(\mathbf{n}=37)\end{array}$ & $\begin{array}{c}\text { p- } \\
\text { value }\end{array}$ \\
Age (year) & $29.46 \pm 5.59$ & $27.27 \pm 4.06$ & 0.061 \\
Gravida & $2.17 \pm 0.98$ & $1.76 \pm 0.98$ & 0.078 \\
Parity & $1.00 \pm 0.87$ & $0.85 \pm 0.82$ & 0.084 \\
BMI (kg/m²) & $29.20 \pm 1.88$ & $27.67 \pm 2.48$ & $0.004^{*}$ \\
Smoking habit & $6(\% 17.1)$ & $9(\% 24.3)$ & 0.453 \\
Week of gestation & $35.77 \pm 1.21$ & $35.14 \pm 0.97$ & 0.568 \\
Delivery week & $38.82 \pm 1.15$ & $38.56 \pm 1.25$ & 0.364 \\
Delivery type & & & \\
Vaginal delivery & $24(\% 68.6)$ & $28(\% 75.7)$ & 0.501 \\
$\quad$ Delivery by cesarean & $11(\% 31.4)$ & $9(\% 24.3)$ & \\
Newborn weight (g) & $3533.48 \pm 448.74$ & $3337.83 \pm 330.10$ & $0.038^{*}$ \\
1-minute Apgar score & $8.06 \pm 0.72$ & $8.38 \pm 0.79$ & 0.078 \\
5-minute Apgar score & $8.77 \pm 0.54$ & $8.92 \pm 0.59$ & 0.278 \\
Fasting blood & $86.94 \pm 8.67$ & $80.97 \pm 5.17$ & $0.001 *$ \\
glucose (mg/dl) & & & \\
Postprandial blood & $120.40 \pm 20.50$ & $104.00 \pm 10.05$ & $0.001 *$ \\
glucose (mg/dl) & & & \\
AMH (ng/ml) & $1.37 \pm 0.80$ & $1.52 \pm 0.99$ & 0.464 \\
\hline
\end{tabular}

AMH: anti-Müllerian hormone; GDM: gestational diabetes mellitus; BMI: body mass index. ${ }^{*} p<0.05$ is statistically significant. the multiple linear regression analysis where serum $\mathrm{AMH}$ level was dependent variable, the regression coefficient was 0.94 and $95 \%$ confidence interval was $-0.06-$ $0.13(\mathrm{p}=0.45)$ for $\mathrm{BMI}$, the coefficient was -0.10 and $95 \%$ confidence interval was $-0.06-0.02(\mathrm{p}=0.41)$ for maternal age, and the coefficient was 0.11 and $95 \%$ confidence interval was $-0.09-0.26(\mathrm{p}=0.34)$ for week of gestation.

\section{Discussion}

In our study, we did not find any difference between pregnant women with GDM and healthy pregnant women in terms of serum AMH levels measured at third trimester. AMH is secreted from the granulose cells of prenatral and antral follicles from fetal life up to the period of menopause. ${ }^{[9-12]}$ In the studies performed in recent years, it has been shown that serum AMH levels may be associated with metabolic conditions such as PCOS and obesity in addition to ovarian reserve. ${ }^{[3,4]}$

The studies performed for the AMH levels during pregnancy showed that AMH levels decrease at the third trimester; although this reduction was determined to be insignificant by some studies, other studies considered it significant. The reason for the decrease is the inhibition of menstrual cycle due to the lowered gonadotropin level and the suppression of follicular development. With the disappearance of follicular suppression after delivery, AMH levels increase. ${ }^{[5,13]}$ GDM is a clinical condition characterized by glucose intolerance, and metabolic and hormonal changes developing during pregnancy ${ }^{[6]}$ The pregnancies complicated with diabetes have both maternal and fetal risks. ${ }^{[7]}$

There are two studies in the literature investigating $\mathrm{AMH}$ levels in patients with GDM. In their study, Villarroel et al. compared healthy pregnant women with those with Type 2 DM and GDM diagnoses, and they found that there was no significant difference between two groups although AMH levels decreased in both groups at the third trimester. ${ }^{[14]}$ Gerli et al. showed in their study that AMH values were correlated with maternal age also during the pregnancy, but they were not affected by GDM, BMI, fetal birth weight and placental weight. ${ }^{[15]}$ In our study, we also found no correlation between $\mathrm{AMH}$ and fetal birth weight, FBG and PBG.

It was shown in the literature that serum $\mathrm{AMH}$ levels and HOMA-IR levels which is the parameter of insulin resistance are associated. ${ }^{[3]}$ Pregnancy is charac- 
terized by a physiological insulin resistance. Nelson et al. carried out a study on AMH levels of pregnant women and they determined GDM as exclusion criteria in their study considering that insulin values and insulin resistance may affect AMH levels. Some authors suggested that the increase in insulin and androgen levels may affect serum AMH values; however, the studies showed that there is no correlation between insulin and AMH values. ${ }^{[16,17]}$ In our study, we found no significant different in terms of serum AMH levels although FBG, PBG and BMI were higher in the GDM group. This supports the result that AMH levels are not affected by insulin and glucose levels in pregnant women.

Lambert-Messerlian et al. reported in their study that $\mathrm{AMH}$ levels in pregnant women were not affected by glucose increase or food intake. ${ }^{[18]}$ Freeman et al. carried out their study on obese and non-obese women, and they found that $\mathrm{AMH}$ levels were lower in obese women than non-obese women. ${ }^{[19]}$ In our study, BMI was higher in the GDM group than the control group, but we found in the multiple linear regression analysis that BMI had no impact on serum AMH values.

\section{Conclusion}

In conclusion, we found no difference between the pregnant women with and without GDM diagnosis in terms of AMH levels at the third trimester. Although $\mathrm{AMH}$ values decrease at the third trimester, increases in serum insulin and glucose levels do not affect $\mathrm{AMH}$ levels. Since there are studies showing that AMH levels are higher in cases with insulin resistance, further studies are needed to reveal the GDM correlation.

Conflicts of Interest: No conflicts declared.

\section{References}

1. Clemente MG, De Virgiliis S, Kang JS, Macatagney R, Musu MP, Di Pierro MR, et al. Early effects of gliadin on enterocyte intracellular signalling involved in intestinal barrier function. Gut 2003;52:218-23.

2. Picon P. Action of the fetal testis on the development in vitro at Müllerian duct in the rat. [Article in French] Arch Anat Microsc Morphol Exp 1983;58:1-19.

3. Wiweko B, Indra I, Susanto C, Natadisastra M, Hestiantoro A. The correlation between serum AMH and HOMA-IR among PCOS phenotypes. BMC Res Notes 2018;11:114.

4. Buyukinan M, Atar M, Pirgon O, Kurku H, Erdem SS, Deniz I. Anti-Mullerian hormone and inhibin B levels in obese boys; relations with cardiovascular risk factors. Exp Clin Endocrinol Diabetes 2018;126:528-33.

5. la Marca A, Giulini R, Orvieto R, Volpe A. Anti Müllerian Hormone concentrations in maternal serum during pregnancy. Hum Reprod 2005;20:1569-72.

6. Colberg SR, Castorino K, Jovanovic L. Prescribing physical activity to prevent and manage gestational diabetes. World J Diabetes 2013;4:256-62.

7. Lawrence JM. Women with diabetes in pregnancy: different perceptions and expectations. Best Pract Res Clin Obstet Gynaecol 2011;25:15-24.

8. American Diabetes Association. Gestational diabetes mellitus. Diabetes Care 2004;27 Suppl 1:S88-90.

9. Visser JA, de Jong FH, Laven JS, Themmen AP. Anti-Müllerian hormone: a new marker for ovarian function. Reproduction 2006;131:1-9.

10. Broer SL, Broekmans FJ, Laven JS, Fauser BC. AntiMüllerian hormone: ovarian reserve testing and its potential clinical implications. Hum Reprod Update 2014;20:688- 701.

11. Dayal M, Sagar S, Chaurasia A, Singh U. Anti-müllerian hormone: a new marker of ovarian function. J Obstet Gynaecol India 2014;64:130-3.

12. Fanchin R, Schonäuer LM, Righini C, Guibourdenche J, Frydman R, Taieb J. Serum anti-Müllerian hormone is more strongly related to ovarian follicular status than serum inhibin B, estradiol, FSH and LH on day 3. Hum Reprod 2003;18: $323-7$.

13. Köninger A, Schmidt B, Mach P, Damaske D, Nießen S, Kimmig R, et al. Anti-Mullerian-hormone during pregnancy and peripartum using the new Beckman Coulter AMH Gen II Assay. Reprod Biol Endocrinol 2015;13:86.

14. Nelson SM, Stewart F, Fleming R, Freeman DJ. Longitudinal assessment of antimüllerian hormone during pregnancy-relationship with maternal adiposity, insulin, and adiponectin. Fertil Steril 2010;93:1356-8.

15. Lutterodt M, Byskov AG, Skouby SO, Tabor A, Yding Andersen C. Anti-Mullerian hormone in pregnant women in relation to other hormones, fetal sex and in circulation of second trimester fetuses. Reprod Biomed Online 2009;18:694-9.

16. Villarroel C, Salinas A, López P, Kohen P, Rencoret G, Devoto L, et al. Anti-Müllerian hormone in type 2 and gestational diabetes during the second half of pregnancy: relationship with sexual steroid levels and metabolic parameters. Gynecol Endocrinol 2018;34:120-4.

17. Gerli S, Favilli A, Brozzetti A, Torlone E, Pugliese B, Pericoli $\mathrm{S}$, et al. Anti-mullerian hormone concentration during the third trimester of pregnancy and puerperium: a longitudinal casecontrol study in normal and diabetic pregnancy. Endocrine 2015;50:250-5.

18. Lambert-Messerlian GM, Straseski JA, Eklund EE, Palomaki GE, Haddow JE. Antimüllerian hormone levels are not altered by glucose challenge or a meal. J Appl Lab Med 2017;2:238-43.

19. Freeman EW, Gracia CR, Sammel MD, Lin H, Lim LC, Strauss JF 3rd. Association of anti-mullerian hormone levels with obesity in late reproductive-age women. Fertil Steril 2007; 87:101-6. 